\title{
WASTE DISPOSAL AND MANAGEMENT SYSTEM IN RURAL AREAS OF MYMENSINGH
}

\author{
S. Sheheli \\ Department of Agricultural Extension Education, Bangladesh Agricultural University \\ Mymensingh-2202, Bangladesh
}

\begin{abstract}
The study was conducted in rural areas of Mymensingh district during March to April 2007. Seventy two households were interviewed and respondents were grouped in three categories: low, medium and high income group to identify the respondent's socio-economic condition, total waste production, processing, utilization and preservation methods of waste. The total organic waste production was unequally proportionate areas among low, medium and high income group. Waste generation was also depending on family size and family income. Smaller family generated less amount of waste while larger family generated huge wastes. High income contributes to generate more wastes. The characteristics such as family size and family income of the respondents had positive and significant relationships with their waste generation. Waste use as many purpose such as manure, fuel, landfill etc. A significant amount of waste generated from domestic animal, specially cowdung have been using as fuel purpose. Only $2.78 \%$ respondents used cowdung as compost in their crop field due to less number of domestic animals and scarcity of fuel wood. But $27.78 \%$ respondents were not used it for any of those purposes. Besides these ashes, kitchen waste, feed wastage etc. are used as manure and landfill purpose. Respondents had no systematic planning in all spheres of production, processing and utilization of organic waste. The respondents were disposing their solid waste at various times. As a result improper processing and preservation of wastes have been occurring serious air and water pollution.
\end{abstract}

Key Words : Waste, Disposal, Management, Rural areas

\section{INTRODUCTION}

Wastes arise in association with almost every human activity and reflect the diversity of man's actions. Some waste may have some value to someone either in its present stage or in a converted stage. The rural organic waste includes agricultural, domestic and rural industrial wastes. Agricultural waste is preliminary originated from animals (excreta and byproducts of dead animals) and plants (leaves, stalks, stubbles and shells) (Varshney, 1987). The nature, proportion and methods of utilization of organic wastes differ widely from place to place. Every farm requires a waste management system, and almost every farm is unique in its combination of waste production, handling, storage, treatment and disposal either by recycling or by discharge. 
There remains unutilized a huge amount of recyclable industrial and organic wastes (cowdung). It is seriously needed to use them in environment friendly way even to protect the civilians from highly degraded and polluted environment. The usual useful source the cowdung production in the country is about 225 million tons (AIS, 2003) and that from other animals and poultry is about 9.3 million tons per year according to the census of agriculture 1996 (BBS, 2003) considering an average production of fresh dung as $9.5 \mathrm{~kg}$ per cattle, $200 \mathrm{~g}$ goat or sheep, $60 \mathrm{~g}$ per local and $233 \mathrm{~g}$ per exotic poultry and 80 g per duck. The total recyclable produce thus stands about 279.88 MT or dry matter product of 139.94 million tons. Considering a dry matter (DM) need of 7.5 ton per hectare for an average yield of agricultural crops, this amount of SW can be used for 932933 hectares of land for double crop (15 t/ha compost) per year which accounts more than total operated land (8293343.73 hectares) of the country. But unfortunately, the major parts of these wastes are wasted and lost due to non-recycling and proper preservation. Washing down to ditches, rivers and burning as fuels, garbaging or land filling etc.

Waste management is a great problem in rural areas of Bangladesh as well as other countries of the world. The wastes play a harmful role to the environment. It pollutes the air, water and soil. When the wastes are thrown in any place they are rotten and produces bad odor. Many micro-organisms work on waste and cause many harmful disease. Rotten wastes produce and create global warming. Waste decomposition frequently pollutes the open water sources (river, pond, lake, etc.) as it reaches there by surface run off with rain water. Sometimes it pollutes the ground water through leaching or percolation with rainwater. It causes $\mathrm{O}_{2}$ deficiency in water and becomes harmful for the fish, bacteria, fungal and other living organism.

At present these wastes are somehow being managed to dispose and dump, which is causing environmental pollution day by day and becoming health hazard. Till to date little attention has been given on this vital issue in Bangladesh to overcome this problem. If it could pay good attention to handle this problem properly waste would be less generous to open water source, ground water and the environment without causing huge monetary involvement.

With these in mind the present study has been undertaken in rural communities of Mymensingh sadar upazila :

1. to identify the existing waste management system and to quantify the amount of waste generated from different sources in rural areas.

\section{METHODOLOGY}

\section{Data source}

The study was conducted in rural areas of Mymensingh sadar upazila. Four villages were selected at random namely, Boira, Sutiakhali and Beltali. The people of the villages are constituted the population. The population constituted 680 households. Among the population, 72 households in rural areas were selected by simple random procedure. A 
structured interview schedule with open-ended and closed-ended questions was developed. Before data collection, a pre-test was run to justify the reliability and validity of the interview schedule. Data were collected through personal interview during March to April 2007.

\section{Measurement of variables}

Total production of organic waste per household was measured by the researchers and expressed in $\mathrm{Kg}$. It was dependent on the number of production components of a farm such as livestock and ashes etc.

At first the total number of cattle present per household during data collection of the farmer in the village was recorded and then the quantity of cowdung was calculated by multiplication of the cowdung production per head/day and the result was expressed in $\mathrm{kg}$. Similar method was also used for estimation of goat faces and poultry excreta. The respondents were the housewives of sampled farmers or the senior women member of the homesteads. The researcher was asked to the respondent about the fuel items and total amount of ash produce per day. Based on her opinion, amount of those ashes were weighed and then calculated for day basis and expressed in $\mathrm{kg}$.

\section{Statistical analysis}

The collected data were compiled, coded and analyzed as per objectives of the study. Statistical means such as frequency, percentage distribution, range, mean, standard deviation (SD) were calculated and finally analysis of variance were performed to find out the differences between selected variables of the research. Also the tables were used to interpret the data. The correlation-coefficient analysis between dependent and independent variables were carried out to find the relationship.

\section{RESULTS AND DISCUSSION}

\section{Characteristics of the respondents}

The highest proportions (47.2\%) of the respondents were middle aged, 30.6\% were young aged and $22.2 \%$ were old aged, respectively (Table 1). Considering educational qualification, only 5.56\% respondents were above secondary level and the highest respondents were belonged to low income groups $47.22 \%$. About two third household had medium family and $19.44 \%$ had large family. In case of occupation, the highest portions of the respondents were agriculture (36.1\%) and lowest portion was rickshaw puller (5.6\%). Average monthly income per household in this country is Tk. 5841.88 (BBS, 2001). Thus, it seems that the monthly income in the study area is higher than the national context since per household had average Tk. 6644.44 in study areas.

The findings in relation to each of the five selected characteristics of the respondents are presented in Table 1 and Table 2 shows the generation of waste according to the respondents family income and family size. 
Table 1. Salient features of the characteristics of the respondents

\begin{tabular}{|c|c|c|c|c|c|c|}
\hline $\begin{array}{l}\text { Characteristics/ } \\
\text { Scoring method }\end{array}$ & \begin{tabular}{|c|} 
Obtained \\
score range
\end{tabular} & Categories & $\begin{array}{c}\text { No. of } \\
\text { respondent }\end{array}$ & Percent & Mean & $\begin{array}{l}\text { Standard } \\
\text { deviation }\end{array}$ \\
\hline \multirow{3}{*}{$\begin{array}{l}\text { Age } \\
\text { (No of year) }\end{array}$} & \multirow{3}{*}{ 17-70 } & Young aged (17-35) & 22 & 30.6 & \multirow[t]{3}{*}{41.33} & \multirow[t]{3}{*}{12.98} \\
\hline & & Middle aged (36-50) & 34 & 47.22 & & \\
\hline & & Old aged (above 50) & 16 & 22.2 & & \\
\hline \multirow{4}{*}{$\begin{array}{l}\text { Educational } \\
\text { qualification } \\
\text { (Score) }\end{array}$} & \multirow{4}{*}{$0-13$} & Illiterate $(0)$ & 24 & 33.33 & \multirow[t]{4}{*}{6.83} & \multirow[t]{4}{*}{2.46} \\
\hline & & Primary level (1-5) & 24 & 33.33 & & \\
\hline & & Secondary level (6-10) & 20 & 27.77 & & \\
\hline & & above Secondary level $(>10)$ & 4 & 5.56 & & \\
\hline \multirow{3}{*}{$\begin{array}{l}\text { Family size } \\
\text { (No. of family } \\
\text { member) }\end{array}$} & \multirow[t]{3}{*}{$2-12$} & Small family (up to 4 ) & 12 & 16.67 & \multirow[t]{3}{*}{6.83} & \multirow[t]{3}{*}{2.46} \\
\hline & & Medium family (5-7) & 46 & 63.89 & & \\
\hline & & Large family (above 8) & 14 & 19.44 & & \\
\hline \multirow{3}{*}{$\begin{array}{l}\text { Family income } \\
\text { (Score in Tk.) }\end{array}$} & \multirow{3}{*}{$3000-12000$} & Low $(<4000)$ & 34 & 47.22 & \multirow[t]{3}{*}{6644.44} & \multirow[t]{3}{*}{4500.76} \\
\hline & & Medium (4001-8000 Tk) & 18 & 25.00 & & \\
\hline & & High $(>8000 \mathrm{Tk})$ & 20 & 27.78 & & \\
\hline \multirow[t]{7}{*}{ Occupation } & \multirow[t]{7}{*}{-} & Job & 10 & 13.9 & \multirow[t]{7}{*}{-} & \multirow[t]{7}{*}{-} \\
\hline & & Agriculture & 26 & 36.1 & & \\
\hline & & Business & 6 & 8.3 & & \\
\hline & & Agriculture and Business & 10 & 13.9 & & \\
\hline & & Student & 8 & 11.1 & & \\
\hline & & House wife & 8 & 11.1 & & \\
\hline & & Rickshaw puller & 4 & 5.6 & & \\
\hline
\end{tabular}

Table 2. Generation of waste according to the family income and family size

\begin{tabular}{c|lc}
\hline \multicolumn{1}{c|}{ Characteristics } & \multicolumn{1}{c}{ Categories } & Average waste generation (kg) \\
\hline Family income level & Low income group(<4000 Tk.) & 13.510 \\
& Medium income group (4001-8000 Tk.) & 27.319 \\
& High income group (>8000 Tk.) & 69.240 \\
Family size & Small family (up to 4) & 16.26 \\
& Medium family (5-8) & 43.88 \\
& Large family (above 8) & 65.70 \\
\hline
\end{tabular}

Relationships between the selected characteristics of the respondents and their waste generation

In this section relationship between each of the five selected characteristics of the respondents and their waste generation were investigated. Pearson's Product Moment Correlation Coefficient ' $\mathrm{r}$ ' was used for this purpose. A summary of the correlation analysis is presented in Table 3. 
Table 3. Observed correlation coefficient ' $r$ ' between characteristics of the respondents and their waste generation

\begin{tabular}{l|c}
\hline \multicolumn{1}{c|}{ Characteristics } & Computed value of " $\mathrm{r}^{\text {" }}(\mathrm{df}=74)$ (waste generation) \\
\hline Age & -0.039 \\
Educational qualification & 0.228 \\
Family size & $0.687^{* * *}$ \\
Family income & $0.825^{* * *}$ \\
Occupation & 0.300 \\
\hline
\end{tabular}

** Correlation is significant at 0.01 level, *** Correlation is significant at 0.001 level

Out of five variables, the relationships of only two variables were significant namely, family size and family income. Age, educational qualification and occupation had no significant relationships with the waste generation.

\section{Waste generation from different rural study areas}

Generated waste was weighed in individual house. Finally these data were statistically analyzed. The results showed that there was significant variation among the study areas of rural region in waste generation. From the recorded data the highest amount of wastes $(47.61 \mathrm{~kg})$ was recorded in village Sutiakhali, while the lowest $(27.30 \mathrm{~kg})$ was recorded in village Boira. The amount of wastes depends on number of livestock specially number of cow. Sutiakhali village had higher number of livestock than that of others. So, the generation of waste was higher (Table 4) in Sutiakhali village.

Table 4. Waste generation from different rural study areas

\begin{tabular}{l|c}
\hline \multicolumn{1}{c}{ Treatments } & Parameter \\
\cline { 2 - 2 } & Amount of waste $(\mathrm{kg} /$ day $)$ \\
\hline Boira & $27.30 \mathrm{~b}$ \\
Sutiakhali & $47.61 \mathrm{a}$ \\
Beltali & $22.41 \mathrm{~b}$ \\
Level of significance & $* * *$ \\
\hline
\end{tabular}

*** Significant at 0.001 level of probability

\section{Problem in waste management system}

In study area, six problems were identified in waste management system. Fast one is dustbin or specific area for waste storing is almost absent. People have been storing their waste on the dustbin, pit, road and drain side, vacant plot, road side and some of the respondent don't know where their waste being stored. There were $16.67 \%$ on the rode side, $22.22 \%$ on vacant plot and $61.11 \%$ response for storing their waste in pit. Second one is respondents have no fixed waste disposal time. From the study it was found that peoples were disposing their waste at various times. It was $41.66 \%$ responses have no fixed time, $25 \%$ disposed their waste at morning, $27.78 \%$ at noon and rest of $5.56 \%$ disposed their waste in the evening. Improper utilization of organic waste is third problem. The $36.11 \%$ respondents used cowdung as fuel purpose (making of ghuta and 
cowdung stick with cowdung), while $33.33 \%$ respondents were used it both compost and fuel purposes. On the other hand, only $2.78 \%$ respondents used cowdung as compost in their crop field due to less number of domestic animals and scarcity of fuel wood. The $27.78 \%$ respondents were not used it for any of those purposes. Storing of waste is forth problem. These problems are categorized as absence of dustbin; dustbin is not in appropriate location or within the walking distance, offensive odour near the bin and lack of manpower for carrying the disposed waste. Lack of higher authority supervision and communities support is five number problems. Last one is Spreading of waste of the surrounding. Among animals dog was the most severe one to spread the waste materials to its surrounding. Similarly, foxes, cat, even cows and some other birds spread waste materials to the surrounding of the structures. It becomes possible due to open side of dustbin.

\section{CONCLUSION AND RECOMMENDATIONS}

It was evident that in all spheres of production, processing and utilization of organic waste, there was no systemic planning among the respondents. In rainy season due to shallow pit, runoff and leaching loss occurs which causes serious water pollution. The most alarming situation was that cowdung, homestead wastes of crops were mostly used as fuel instead of manuring the crop field. This practice led to serve environmental problem and made the land vulnerable due to shortage of organic matter in soil. Furthermore, improper processing and preservation of wastes have been occurring serious air and water pollution.

The following options may be suggested to overcome the problems related to production, processing, preservation and utilization of organic waste.

i. Motivation of the community people is essential.

ii. Judicious and efficient use of organic waste as fuel through improved chula and organic fertilizer through balanced way may be done.

iii. Proper methods of processing (composting) and preservation for efficient management is essential.

iv. Government intervention is needed to overcome the problems.

v. Making/amending and implementing of the legislation regarding waste disposal and management system is needed.

\section{REFERENCES}

AIS (Agricultural Information Service) 2003. Krishi Diary 2003. (In Bangla). Agril. Inf. Serv., Khamar Bari, Farmgate, Dhaka.

BBS (Bangladesh Bureau of Statistics). 2003. Year Book Agricultural Statistics of Bangladesh, 2001. Bangladesh Bur. of Stat. Stat. Divn. Minis. Planning, Govt. People's Repub., Bangladesh, Dhaka. pp. 37-40.

Varshney, A. C. 1987. Rural Waste Management. Central Inst. Agril. Engg. Bhopal. Associate Publishing Company. Karol Bagh. New Delhi, India. 